\title{
Transformasi Konsep Diri Jamaah Haji (Studi Fenomenologi pada Kelompok Bimbingan Ibadah Haji Lembaga Haji Muhammadiyah Jawa Barat)
}

\author{
Imron Rosyidi, Encep Dulwahab \\ UIN Sunan Gunung Djati Bandung, Indonesia \\ imronrasyidi@yaboo.com, encep.dulwahab@uinsgd.ac.id
}

\begin{abstract}
Absract
Hajj is one of the most complex worship services. Not only does it require psychic and physical strengths, but it also requires comprehensive and consistent understanding and experience. Many changes in self occur in the congregation when the pilgrimage. This is the purpose of this research, which is to find out the transformation of the hajj pilgrims' self-concept before and after the Hajj. By using a qualitative method of the phenomenological perspective, the results of this research indicate that there are several self-concepts of pilgrims, including: prospective hajj pilgrims are not good at reciting, hajj candidates are less close to the Khaliq, and hajj candidates have less concern for others. In addition, there is a self-concept of pilgrims after Hajj. There is a transformation of selfimage with a "new status" as a hajj mabrur as a way to make oneself deserve to be called Hajj with frequent prayers in congregation in the mosque and caring for others.
\end{abstract}

Keyword: Pilgrims, Pilgrimage, Communication, Self-Concept, Transformation

\begin{abstract}
Absrak
Ibadah haji merupakan salah satu ibadah yang paling kompleks. Tidak hanya membutuhkan psikis dan fisikyang kuat, tetapijuga pemahaman dan pengalaman yang komprehensif dan tentu saja konsisten. Banyak perubahan diri terjadi pada diri jamaah ketika pelaksanaan ibadah haji. Inilah yang menjadi tujuan penelitian ini yaitu untuk mengetahui transformasi konsep diri jamaah haji sebelum dan setelah melaksanakan ibadah haji. Dengan menggunakan metode kualitatif perspektif fenomenologi, hasil penelitian ini menunjukkan bahwa terdapat beberapa konsep diri jamaah haji, di antaranya: calon haji kurang pandai mengaji, calon haji kurang mendekatkan diri pada Sang Khaliq, calon haji kurang memiliki kepedulian kepada orang lain. Dan konsep diri jamaah haji setelah berhaji, terjadi transformasi citra diri dengan "status baru" sebagai haji mabrur yang berusaha memantaskan diri untuk layak disebut haji dengan sering shalat berjamaah di masjid dan peduli dengan orang lain.
\end{abstract}

Kata Kunci: Jamaah, Haji, Komunikasi, Konsep Diri, Transformasi

Permalink/DOI: https://doi.org/10.18326/infsl3.v13i2.279-304 


\section{Pendahuluan}

Ibadah haji termasuk salah satu rukun Islam yang bersifat multidimensional dan kompleks. Karena di dalam ibadah haji memadukan berbagai aspek, mulai dari aspek perjalanan, ritual, fisik dan mental spiritual, yang semuanya dilaksanakan dalam waktu dan tempat yang telah ditentukan. Semua aspek tersebut melibatkan interaksi dan komunikasi, baik antara sesama manusia maupun dengan Tuhan.

Prosesi ibadah haji seperti berihram, thawaf di Ka'bah, wukuf di Arafah, mabit dan melempar jumroh di Mina, merupakan proses simbolik yang sarat makna dan memiliki nilai yang tinggi. Di antara makna dan nilai-nilai dalam ibadah haji dapat mempengaruhi konsep diri bagi orang yang melaksanakannya. Dan nilai-nilai dalam ibadah haji, tidak terdapat pada ibadah-ibadah lainnya. Makna dan nilai dalam ibadah haji bisa dilihat salah satunya pada pakaian ihram yang digunakan ketika berhaji. Menurut Wolfe (2003:209), bahwa pakaian ihram memiliki pengaruh pada diri seorang yang berhaji, yaitu meniadakan perbedaan kelas antara kaya dan miskin, berpendidikan atau tidak, terhormat atau tidak. Kain ihram menunjukkan kesetaraan di antara umat muslim.

Dalam konteks perubahan sosial, Abdurrahman (2009:257) menyebutkan bahwa aktivitas ziarah haji merupakan arena penting dalam produksi sosial. Ziarah haji telah menghasilkan kemampuan menciptakan arti baru dalam perubahan sosial.

Ibadah haji berpengaruh pada perubahan identitas, status sosial dan harga diri untuk orang yang menunaikan haji. Victor Turner (dalam Abdurrahman, 2009:8-9) mengatakan bahwa sekembalinya dari Tanah Suci, jamaah haji kalangan kelas menengah, tidak hanya mengubah semangat keagamaannya, tetapi juga merayakan kelahiran kembali dirinya melalui pencitraan diri dihadapan publik, dan pada momen-momen tertentu senantiasa mengadakan pertunjukan budaya sebagai upaya peneguhan identitas kelas sosial yang amat jelas.

Banyak motif umat Islam untuk melaksanakan ibadah haji, khususnya masyarakat muslim Indonesia yang sangat antusias un- 
tuk melaksanakannya, baik masyakarat perkotaan maupun pedesaan, mereka yang mampu melaksanakannya menunjukkan kelas sosial yang lebih tinggi, dan sebagai upaya mendongkrak status sosial. Tidak hanya itu, ibadah haji mampu membentuk citra diri sebagai orang soleh. Khususnya pasca pelaksanaan ibadah haji, yang merupakan tahapan di mana umat Islam mengkonstruksi realitas kehidupan sosialnya secara sedemikian rupa sehingga terbentuk realitas yang unik dan khas.

Tentu tidak semua orang yang telah berhaji memiliki motif sebagaimana digambarkan di atas, ada juga orang yang berhaji dengan tujuan mulia, yaitu ingin memperkuat keimanan dan istiqomah dengan ibadahnya sekembalinya ke tanah air. Mengenai motif umat muslim yang berhaji dengan tulus dan ikhas, pernah diteliti oleh Agus Romdlon Saputra dengan judul penelitian Motif dan Makna Sosial Ibadah Haji Menurut Jama'ah Masjid Darussalam Wisma Tropodo Waru Sidoarjo, hasilnya menunjukkan bahwa, motif menunaikan ibadah haji sebagai bagian dari kebutuhan biologis makhluk hidup yang sehat. Selain itu, ada juga motif semata-mata menjalankan titah dan perintah Allah Swt, dalam menyempurnakan rukun Islam yang lima, atau tujuan mendekatkan diri kepada Allah Swt (2016:89).

Ada pengalaman luar biasa yang dirasakan jamaah haji sepulangnya dari menunaikan ibadah haji, yang berhasil diteliti oleh Budi Kisworo dengan judul penelitian Ibadah Haji Ditinjau Dari Berbagai Aspek, hasil penelitiannya menunjukkan bahwa seorang yang telah pulang dari menunaikan ibadah haji dan umrah itu ibarat bayi, segala dosanya diampuni, dan ia ibarat dilahirkan kembali (2017: 97).

Pelaksanaan ibadah haji bagi seorang muslim merupakan dinamika gerakan Islam, yang membentuk bangunan simbolis pengalaman dan identitas sosial seorang muslim, yang diharapkan dapat menghasilkan sebuah perubahan menyangkut kesadaran peranan individu dalam masyarakat. Umat muslim setelah berhaji banyak yang mengalami pergeseran konsep diri. Ada perubahan pola dan bentuk komunikasi orang-orang yang telah melakukan haji dengan masyarakat sekitarnya. 
Para jamaah haji yang mengalami perubahan konsep diri dipengaruhi oleh beragam faktor, menurut Fithria dalam hasil penelitannya tentang Hubungan Komunikasi Keluarga dengan Konsep Diri Remaja bahwa konsep diri seseorang tidak terbentuk sewaktu lahir, tetapi dipelajari sebagai hasil dari pengalaman unik seseorang dalam dirinya sendiri dengan orang terdekat, dan dengan realita dunia (2011: 32).

Kemudian hasil penelitian Sapto Irawan yang melakukan penelitian tentang Pengarub Konsep Diri terhadap Komunikasi Interpersonal Mahasiswa, menunjukkan bahwa konsep diri seseorang mempengaruhi komunikasi interpersonal (2017: 48). Banyak jamaah haji yang mengalami perubahan pola komunikasi dengan orang lain ketika dia mengalami perubahan konsep diri. Dulu sebelum berhaji ketika berkomunikasi dengan orang lain begitu dekat, tetapi setelah berhaji, seperti menjaga jarak sehingga tidak lagi akrab dengan masyarakat sekitar.

Perubahan-perubahan konsep diri orang yang telah berhaji ini sangat mempengaruhi ketika mereka berinteraksi atau berkomunikasi dengan masyarakat sekitarnya. Tine Agustin Wulandari menunjukkan bahwa hubungan sangat erat antara konsep diri dengan efektivitas komunikasi antarpribadi dalam hasil penelitiannya tentang Hubungan Antara Konsep Diri Dengan Keefektivan Komunikasi Antarpribadi (2014: 205).

Adanya transformasi konsep diri yang dialami orang berhaji inilah yang menarik untuk diteli. Karena tidak sedikit orang telah melaksanakan ibadah haji mengalami transformasi konsep diri, tentu ada juga Jemaah haji yang tetap istiqamah dan semakin soleh setelah berhaji.

\section{Transformasi Konsep Diri}

Menurut William D. Brooks (dalam Rakhmat, 1999:99) konsep diri adalah pandangan dan perasaan tentang diri sendiri, dan bisa bersifat pandangan dan perasaan psikologi, sosial dan fisik, yang diperolehnya melalui pengalaman dan interaksi dengan orang lain.

Konsep diri merupakan faktor yang sangat menentukan dalam komunikasi interpersonal, karena setiap orang bertingkah laku 
sedapat mungkin sesuai dengan konsep dirinya. Kecenderungan untuk bertingkah laku sesuai dengan tingkah laku disebut dengan membuat yang dipenuhi sendiri. Bila seseorang berpikir ia bodoh, ia akan benar-benar menjadi orang bodoh. Bila seseorang merasa memiliki kemampuan untuk mengatasi persoalan, maka persoalan apapun yang ia hadapi pada akhirnya dapat ia atasi. Seseorang berusaha hidup sesuai dengan label yang ia lekatkan pada dirinya.

Di dalam konsep diri, ada dua komponen yang selalu beriringan, yaitu komponen kognitif dan komponen afektif. Komponen kognitif yaitu seseorang yang berusaha melakukan self image (citra diri), dan komponen afektif seseorang yang berusaha melakukan self esteem (harga diri). Kedua komponen ini memiliki pengaruh yang besar dalam perkembangan atau perubahan konsep diri.

Konsep diri ini tidak dimiliki secara otomatis, tetapi ada faktor eksternal yang mempengaruhinya. Ada dua faktor yang mempengaruhi konsep diri, yaitu faktor orang lain dan kelompok rujukan (Rakhmat, 2015: 99-102). Orang lain yang mempengaruhi konsep diri seseorang tidak semua, tetapi hanya orang-orang tertentu yang memiliki pengaruh kuat. Biasanya orang yang memiliki pengaruh kuat adalah mereka yang paling dekat dan intentif berinteraksi, paling memiliki keunggulan, kelebihan, kekuatan dengan diri seseorang. George Herbert Mead (1934) menyebut mereka yang penting dan pengaruh kuat dengan istilah significant others (orang lain yang sangat penting), di antaranya adalah orang tua, saudara dan orang yang tinggal satu rumah. Melalui orang-orang kuat dan berpengaruh inilah konsep diri terbentuk. Atau orangorang yang sering dekat dan mengajarkan kita tentang kehidupan. Orang-orang ini Richard Dewey dan W.J. Humber (1966: 105) menyebutnya effective others, yaitu orang-orang yang memiliki ikatan emosi yang dekat. Merekalah yang pertama kali mengajarkan penghargaan dan menyebabkan kita menilai diri kita secara positif atau sebaliknya negatif.

Faktor lain yang juga mempengaruhi konsep diri seseorang, yaitu reference group (kelompok rujukan) yang seseorang senantiasa beraktivitas dan melakukan interaksi dengan sesama anggota kelompok tersebut. Dan kelompok ini memiliki pengaruh kuat 
dalam perubahan konsep diri seseorang. Kelompok rujukan ini bisa dari pergaulan seseorang di sekolah, kampus, dalam tempat kerja, dan dalam kehidupan bermasyarakat.

Dalam setiap fase perkembangan manusia selalu memiliki kelompok yang menjadi tempatnya untuk berekspresi, berbagi pengalaman, dan membentuk konsep diri. Besar atau kecil konsep diri seseorang akan terpengaruh oleh kelompoknya. Karena setiap kelompok mempunyai norma, aturan, nilai dan budaya tertentu. Dan terkadang kelompok-kelompok ini yang secara emosional mengikat diri seseorang, dan orang tersebut susah melepaskannya.

Konsep diri seseorang dapat mengalami perubahan, bahkan sampai pada perubahan identitas sebagaimana dikatakan Anselm L. Strauss (1969:89). Manusia sejak lahir senantiasa berubah, karena rasa ingin tahu, ingin mencoba, manusia tidak bisa tidak untuk berinteraksi dengan orang lain, dan manusia ingin merasakan adanya perubahan ke arah yang lebih baik dalam hidupnya. Upayaupaya untuk memenuhi itu semua, maka manusia mau tidak mau akan melakukan perubahan, di antaranya perubahan konsep diri.

\section{Metodologi}

Penelitian ini menggunakan metode kualitatif dengan perspektif fenomenologis, dengan tujuan bahwa penelitian ini mencoba memperoleh gambaran yang mendalam, serta pemahaman yang holistik berdasarkan situasi yang wajar (natural setting) tentang transformasi konsep diri jamaah haji yang diteliti. Dalam penelitian ini, peneliti bertindak sebagai instrumen kunci untuk memperoleh data yang dibutuhkan.

Mengenai perspektif fenomenologi, Bungin (2003:9) mengatakan bahwa fenomenologi pada dasarnya berpandangan bahwa apa yang tampak di permukaan, hanyalah sesuatu gejala atau fenomena dari sesuatu yang tersembunyi di "kepala" sang pelaku. Perilaku apapun yang tampak di tingkat permukaan baru bisa dipahami atau dijelaskan manakala bisa mengungkap apa yang tersembunyi dalam dunia pengetahuan si pelaku. Realitas sesungguhnya bersifat subjektif dan maknawi. Ia bergantung pada persepsi, pemahaman dan anggapan-anggapan seseorang. Disitulah letak kunci jawaban terhadap apa yang terekspresi. 
Sumber data utama dalam penelitian kualitatif adalah katakata dan tindakan, dan selebihnya adalah data tambahan seperti dokumen dan lain-lain. Pemilihan informan (subjek penelitian) dalam penelitian ini didasarkan pada seleksi komprehensif pada jamaah haji yang tergabung dalam Kelompok Bimbingan Ibadah (KBIH) Lembaga Haji Muhammadiyah Jawa Barat. Teknik pengumpulan data yang digunakan dalam penelitian ini adalah observasi partisipatif, wawancara mendalam, analisis dokumen, dan studi pustaka yang berkaitan dengan transformasi konsep diri jamaah haji.

\section{Hasil dan Pembahasan}

Berdasarkan data yang didapatkan, ada dua masa jamaah haji melakukan transformasi konsep diri, yaitu sebelum menunaikan ibadah haji, dan setelah melaksanakan ibadah haji. Namun secara keberlanjutan, ada tiga proses transformasi konsep diri jamaah haji, yaitu sebelum berhaji, selama berhaji, dan sesudah pelaksanaan ibadah haji.

Sebelum berhaji mereka bergabung dalam kelompok bimbingan, mengikuti kegiatan manasik haji secara berkala dalam waktu yang telah ditentukan. Dalam tahapan tersebut mulai terjadi saling kenal antara sesama calon jamaah satu kelompok bimbingan.

Selanjutnya, proses transformasi konsep diri berlangsung dalam proses pelaksanaan ibadah haji yang terjadi dalam waktu 40 hari. Berbagai rangkaian ibadah haji dilaksanakan para jamaah haji ini. Selama menunaikan ibadah haji, banyak pengalaman ritual ibadah haji yang begitu membekas dan berkesan di dalam diri jamaah haji. Dan setelah kembali ke tanah air, para jamaah haji masih terus bertransformasi konsep diri, dengan melalui kegiatan silaturahmi yang difasilitasi oleh kelompok bimbingan yang dilaksanakan secara berkala, biasanya setiap tiga bulan sekali.

\section{Konsep Diri Pra-Haji}

Ilmu Agama yang Kurang

Jemaah mengaku menjelang berangkat haji belum mampu memiliki bekal ilmu agama yang memadai untuk beribadah haji. Di antaranya Jemaah haji belum mampu menghafal dan memahami doa-doa haji, belum mampu membaca Al-Quran dengan benar, dan ajaran-ajaran agama lainnya. 
Realitas tersebut ditemukan sejak mulai melaksanakan bimbingan manasik di kelompok bimbingan, mereka membutuhkan panduan doa-doa haji dengan teks Arab yang disertai transliterasi dengan teks Latin. Realitas tersebut menggambarkan citra diri negatif pada diri Jemaah haji dalam aspek ibadah.

Sebagian dari jemaah haji menyatakan bahwa dirinya "mualaf", artinya benar-benar tidak pernah belajar agama Islam secara formal dalam hidupnya, sehingga Jemaah haji masih belajar membaca Al-Quran, dan menyatakan keinginan untuk belajar memperbaiki bacaannya sebelum berangkat haji, atau selama berada di tanah suci.

Pikiran dan perasaan kurangnya pemahaman ilmu agama senantiasa menghantui calon jemaah haji, dan merasa kurang siap untuk berangkat haji. Calon jemaah haji sebelum berangkat haji merasakan beban psikologis, baik secara kognitif maupun afektif. Mereka banyak yang bingung menghadapi perjalanan haji yang merupakan perpaduan antara dua dimensi penting, yaitu perjalanan fisik dan serangkaian praktik ritual tertentu, dengan keharusan menghafal doa-doa yang menjadi bagian penting dari pelaksanaan ibadah haji.

Tidak hanya calon jamaah haji di Lembaha Haji Muhammadiyah Jawa Barat, Kholilurrohman juga mengatakan bahwa tidak setiap jamaah haji paham secara mendalam mengenai rangkaian ibadah haji. Terutama para jamaah lansia yang mengalami penurunan daya kognisi dan membuatnya sulit untuk belajar (2017:235).

Hal yang sama juga dikatakan Japeri bahwa kebanyakkan calon jamaah haji tidak berlatar belakang pendidikan agama, sehingga cukup terbatas pengetahuannya tentang agama, apalagi tentang tata cara pelaksanaannya yang kebanyakan fisik dan dilaksanakan di Arab yang berbeda adat-istiadat (2017:117). Kondisi-kondisi inilah yang tidak sedikit menyebabkan para calon jamaah haji bingung, cemas, dan ada juga yang stress.

Rendabnya Amalan Ibadab dan Melanggar Ajaran Agama

Menjelang berangkat haji banyak godaan, tantangan, dan rintangan-rintangan yang tidak mudah dilewati oleh para calon 
jamaah haji. Terdapat berbagai godaan dalam diri calon jamaah haji. Tidak sekali terjadi muncul perasaan dan keinginan memindahkan uang haji ini untuk keperluan lain. Karena mengenai biaya haji yang terhitung tidak murah merupakan tantangan tersendiri di kalangan calon jamaah haji untuk memiliki keyakinan yang penuh pada saat berniat melaksanakan haji, dan mulai menabung di rekening tabungan haji. Seringkali muncul godaan untuk mengalihkan niat suci yang sudah terbangun sebelumnya, untuk membelanjakan uang tersebut untuk keperluan-keperluan lain. Ini diperlukan kemantapan hati untuk dapat mewujudkan niat berhaji.

Setelah calon jamaah haji ini berhasil mendaftarkan diri berhaji, cobaan dan masalah berikutnya ialah calon jamaah haji merasa kurang dalam melaksanakan ibadah. Terutama dalam menunaikan shalat lima waktu, mulai dari tata cara pelaksanaannya yang belum memahami secara utuh dan benar, ketepatan waktunya yang seringkali di akhir karena berbagai kesibukan, tempat melaksanakannya yang tidak memahami tempat yang bersih dan layak untuk didirikan shalat, dan rutinitasnya yang padat membuat shalat menjadi bukan kewajiban dan tuntutan untuk seorang muslim.

Kemudian ketika mendekati keberangkatan haji, calon jamaah haji ini berusaha mengubah diri dengan meningkatkan frekuensi dan kualitas ibadahnya, mulai dari memperbaiki pelaksanaan shalat, baik fardu maupun sunah, bangun menjelang waktu subuh untuk mendekatkan diri kepada Allah Swt., melaksanakan shalat tahajud, dan shalat subuh di awal waktu secara berjamaah, baik di rumah maupun di masjid.

Sebelum berangkat haji, calon jamaah haji sudah membayangkan suasana di tanah suci. Hal inilah yang menjadikannya terdorong untuk mempersiapkan kondisi spiritual agar lebih baik, lebih giat beribadah, dan menyambut ritual haji dengan memulai membuat perubahan pada diri agar menjadi orang yang lebih religius.

Semakin mendekati pemberangkatan, ada perubahan konsep diri, yaitu para calon jamaah haji intensif menambah wawasan dan pemahaman keagamaannya, khususnya dalam bidang haji, calon jamaah haji mempelajari dari berbagai literatur, baik melalui bukubuku keagamaan maupun situs internet yang menyajikan informasi 
agama dan haji.

Perubahan-perubahan konsep diri calon jamaah haji menjelang berangkat juga dipengaruhi oleh orang-orang lain dan lingkungannya. Orang lain mulai dari keluarga, dan orang-orang yang senantiasa bertemu melakukan manasik haji di KBIH. Mulailah calon jamaah haji ini secara perlahan namun pasti ada inisiatif dan mandiri untuk mendalami tentang haji. Menurut Saerozi, bahwa munculnya kemandirian calon haji dalam aspek ibadah dan perjalanan, tidak selalu bersifat individual, tetapi juga bersifat kolektif (Saerozi, 2014: 45). Kemandirian kolektif ini karena adanya kesamaan di antara sesama calon jamaah haji di KBIH.

Selain rendahnya calon jamaah haji ini dalam beribah, juga sebagian calon jamaah haji mengaku masih banyak berbuat dosa, baik kepada diri sendiri maupun kepada orang lain. Hal tersebut juga diketahui dari niat dan dorongan untuk berhaji yang sebagian dari mereka berhaji dengan maksud untuk mengubah dan memperbaiki diri. Dengan haji mereka berharap bisa menjaga diri agar tidak lagi berbuat dosa dan melanggar ajaran-ajaran agama Islam.

Perbuatan-perbuatan yang melawan ajaran agama ini susah dan berat untuk dihilangkan. Karena dalam kehidupan sehari-hari, para calon jamaah haji beraktivitas dan profesinya dekat dengan situasi yang dapat menggoda keimanan mereka, khususnya yang bekerja di perusahaan yang sudah terbiasa melakukan praktik tindakan korupsi. Namun menjelang keberangkatan, pikiran-pikiran calon jamaah haji senantiasa terus dihantui dengan perasaan bersalah, dan ketakutan akan dibalas perbuatan-perbuatannya selama berhaji di Arab.

Secara psikologis calon jamaah haji ketika menjelang berangkat haji seringkali diungkapan dengan "Saya pasrah saja". Mereka tetap memberanikan diri untuk berhaji dengan niat untuk memperbaiki diri agar menjadi lebih baik dibanding sebelumnya. Dalam hatinya para calon jamaah haji ini senantiasa berharap agar walaupun secara keilmuan masih belum mumpuni, semoga Allah memaafkan, dan melindunginya.

\section{Kurangnya Kepedulian kepada Orang Lain}

Realitas lainnya yang juga ditemukan di antara calon jamaah 
haji yang masih kurang peduli kepada orang lain, baik kepada orang dekat maupun orang lain yang memerlukan bantuan. Baik pikiran, tenaga, maupun materi bentuk bantuannya.

Tidak hanya masalah ritual ibadah yang menjadi indikator keimanan seseorang, tetapi juga bisa dilihat dari kepedulian kepada orang lain, ketika orang lain sedang membutuhkan pertolongan. Kepedulian kepada orang lain ini juga bisa menjadi parameter untuk mengukur kemabruran haji seseorang.

Namun seiring dengan bertambahnya ilmu dan banyaknya orang sekitar yang memberi saran agar berbuat baik pada orang lain, agar kebaikan yang dilakukannya dibalas dengan berbagai doa sehingga dimudahkan segala urusan selama menunaikan ibadah haji di Arab. Maka calon jamaah haji ini pun mengubah dirinya menjadi orang yang peduli dengan orang lain.

Adanya kesadaran untuk membantu orang lain dari calon jamaah haji juga karena meningkatnya kesadaran untuk lebih giat lagi beribadah. Karena peningkatan pengamalan ajaran agama, akan mempengaruhi kepribadian seseorang dan perilaku toleransi orang tersebut (Saliyo, 2018: 82).

\section{Meningkatkan Status Sosial}

Salah satu faktor yang mendorong calon jamaah haji ini melaksanakan ibadah haji, yaitu karena kebiasaan orang-orang di sekitarnya memanggil Bapak Haji atau Ibu Hajjah kepada orang yang telah pergi berhaji, sehingga di antara calon jamaah haji ini menjadikan panggilan tersebut sebagai motivasi untuk dapat melaksanakan ibadah haji.

Keinginan tersebut juga karena lingkungan dan keluarga yang mendukung. Kakek nenek, orang tuanya calon jamaah haji ini ratarata sudah berhaji. Walhasil kalau belum berhaji secara status sosial belum bisa dikatakan sebagai orang yang mampu secara ekonomi, dan belum bisa masuk pada keluarga besar yang kebanyakan sudah berhaji.

Fenomena ini Abdurrahman menyebutnya sebagai bentuk ibadah haji yang bisa terbolong kepada drama sosial dan pertunjukan sosial (Abdurrahman, 2009: 247). Mereka yang berjuang pergi ke 
haji bukan untuk meraih ridha dan mendapatkan rahmat-Nya, tetapi ingin mendapatkan pujian dari orang-orang sekitarnya, sehingga dia akan dipandang sebagai orang yang secara status sosial tinggi.

\section{Konsep Diri Pasca Haji}

Banyak hikmah dan manfaat dengan ibadah haji. Di antaranya dengan pelaksanaan ibadah haji dapat menghapuskan diskriminasi ras, warna kulit, mencairkan perbedaan karena kedudukan dan keturunan antara sesama manusia. Haji juga sebagai lambang persatuan umat muslim dari berbagai negara, sebagai latihan dalam mengarungi perjalanan kehidupan yang Panjang, dan sebagai gambaran kehidupan manusia yang akan memasuki jenjang berikutnya. Dengan seseorang yang telah melaksankan haji dapat menjadi pendorong baginya dalam upaya menjauhkan diri dari segala bentuk maksiat, karena selalu ingat kematian. Melatih kesabaran dalam menghadapi kesulitan dan rintangan dalam melaksanakan ibadah (Dirjen Penyelenggaraan Haji dan Umrah, 2015: 78-82).

Siapa pun akan mengalami transformasi konsep diri ketika melakukan ibabah haji, juga yang dirasakan oleh salah satu tokoh kulit hitam di Amerika Serikat, dia merasa kalau perjalanan ibadahnya ke Makkah bisa memperluas jangkauannya mungkin lebih dari dua belas hari dibandingkan pengalaman sebelumnya selama tiga puluh sembilan tahun berada di bumi (Malcom X, 1965: 166).

Banyaknya perubahan konsep diri para jamaah haji, karena dipengaruhi kondisi lingkungan yang relijius, banyaknya nilai-nilai keagamaan yang tertanam dalam diri jamaah selama menunaikan haji (Hamidah dan Anganthi, 2017: 94). Karena mereka selama 40 hari secara intensif beribadah. Pikiran, tenaga, dan aktivitasnya semua fokus pada ibadah haji. Tidak ada pekerjaan lain selain beribadah di tanah suci. Berikut beberapa perubahan konsep diri jamaah haji pasca melaksanakan ibadah haji.

\section{Berusaha Menambah Ilmu dan Lebih Mendekatkan Diri}

Konsep diri pasca ibadah haji yaitu adanya transformasi citra diri baru pada jamaah haji dalam aspek ibadah ritual dengan terjadinya peningkatan, baik dari sisi frekuensi maupun kualitas pelaksanaan. Shalat menjadi salah satu indikator penting berkaitan dengan konsep diri seorang yang telah melaksanakan ibadah haji, 
sebab shalat memiliki posisi yang fundamental, pondasi dan pilar bangunan keislaman.

Dalam kehidupan masyarakat Indonesia, mereka seringkali mengukur keberhasilan seseorang dalam melaksanakan ibadah haji melalui indikator yang sederhana, yaitu shalat. Kalau seseorang yang sudah berhaji tidak pernah shalat berjamaah ke masjid, maka masyarakat akan memberi catnya negatif.

Shalat fardu secara berjamaah di masjid merupakan realitas yang terjadi di masyarakat Indonesia, bagi orang yang sudah melaksanakan ibadah haji, tapi jarang atau tidak pernah melaksanakan ibadah salat lima waktu secara berjemaah di masjid dengan sebutan "haji dulmajid" sebagai singkatan dari haji "haji ngedul ka masjid" yang artinya seorang yang sudah berhaji tapi malas pergi ke masjid.

Seorang muslim yang sudah berhaji memiliki tuntutan dalam diri untuk lebih memiliki nilai-nilai yang menggambarkan pribadi seorang muslim yang ideal. Gambaran tersebut tercermin dalam aspek ibadah ritual seperti kemampuan membaca doa-doa dalam salat, penguasaan terhadap makna doa-doa dalam shalat, kemampuan membaca Al-Quran, dan pemahaman terhadap makna teks Al-Quran.

Indikator-indikator tersebut dianggap signifikan berkaitan dengan peran baru di masyarakat, yang seringkali menganggap seorang yang sudah melaksanakan ibadah haji telah menjadi orang yang sudah "naik pangkat", sehingga memberikan peran-peran baru yang seringkali menjadi tuntutan di tengah masyarakat muslim di Indonesia. Seperti menjadi imam shalat, memimpin doa saat berlangsung acara keagamaan, atau acara tertentu di masyarakat.

Untuk menyesuaikan dengan peran barunya, seorang yang sudah berhaji melakukan berbagai upaya. Dalam aspek bacaan AlQuran ia berusaha untuk memperbaiki tajwidnya. Sedangkan untuk lebih memahami artinya ia berusaha mempelajari artinya melalui usaha secara individual, maupun melalui kajian kelompok ikatan alumni jamaah haji yang telah dibentuk. Sebagian kelompok juga menyelenggarakan pertemuan rutin, yang diselenggarakan oleh kelompok regu yang berjumlah 11 orang, yang pelaksanaannya 
dilakukan secara rutin bulanan, dengan mengambil tempat secara bergiliran di rumah anggota kelompok regu.

Dalam rangka menjaga kemabruran dan meningkatkan kesalehan individual seorang yang telah berhaji menuju kesalehan sosial, pemerintah terus berupaya melakukan pembinaan jamaah usai para jamaah ini kembali ke tanah air. Inilah yang disebut pembinaan pasca haji kepada para jamaah haji (Rokhmad, 2016: 162-163).

Seorang muslim yang telah menyelesaikan ibadah haji semestinya menjalankan seluruh perintah agama. Hal tersebut sebenarnya sudah menjadi kewajiban setiap pribadi muslim. Akan tetapi pasca ibadah haji seluruh kewajiban ibadah tersebut menjadi lebih dituntut, baik secara pribadi maupun oleh masyarakat.

Ibadah-ibadah tersebut menyangkut ibadah mahdah seperti shalat fardu, shalat sunnah, membaca Al-Quran dan amal ibadah lainnya. Demikian pula dalam aspek ibadah sosial, seorang muslim yang telah selesai melaksanakan haji, berkewajiban untuk menjaga nilai-nilai yang dimanifestasikan dalam sikap dan perilaku yang menggambarkan kemabruran hajinya.

Perubahan pada diri seorang muslim setelah selesai melaksanakan ibadah haji, bisa diindikasikan dengan keaktifan menjalankan ibadah ritual shalat lima waktu, disertai dengan melaksanakan shalat sunnah secara rutin, berdoa dan berzikir kepada Allah menjadi lebih banyak.

Ibadah haji menjadi momentum perubahan diri bagi seorang muslim, terutama dalam ibadah "mahdoh", ibadah yang bersifat vertikal antara seorang hamba dengan Tuhannya. Dan seorang yang sudah berhaji hendaklah mengamalkan nilai-nilai positif yang terkandung dalam ibadah haji dalam kehidupan sehari-hari.

Haji merupakan pengalaman keagamaan yang dapat mengubah konsep diri diri seseorang. Menurut Ahyadi (2005:185) Pengalaman keagamaan yang khas menjadi bukti akan keberadaan Tuhan yang memiliki sifat-sifat kesempurnaan. Dari beberapa pengakuan mengenai pengalaman berhaji dapat dijelaskan bahwa melalui ibadah haji seorang merasa menjadi sangat dekat dengan Allah SWT. 
Konsep diri jamaah haji yang lebih rajin beribadah karena ada persoalan penting pasca ibadah haji, yaitu mempertahankan kemabruran hajinya. Inilah yang beratnya, karena tidak sedikit jamaah haji yang telah berkorban materi dan tenaga, tetapi tidak mendapatkan mabrur hajinya. Tetapi hanya liburan semata ketika ibadah haji.

Menurut Abdurrahman (2009:92) kaum muslimin percaya bahwa ada dua jenis orang yang kembali dari menunaikan ibadah haji. Pertama, orang yang disebut sebagai haji mabrur, yaitu yang tetap mempertahankan praktik kesalehan keislamannya setelah begitu selesai menunaikan ibadah hajinya. Kedua, orang yang disebut mardud, yaitu orang yang kembali melaksanakan perbuatanperbuatan terlarang sepulangnya dari haji.

Dalam bukunya yang diterjemahkan ke dalam bahasa Indonesia, Islam di Hindia Belanda, Snouch Hurgronje menjelaskan adanya perubahan orang yang pulang dari tanah suci (dalam Abdurrahman, 2009: 81-82), yaitu mereka menjadi lebih fanatik dan gila-gilaan karena sudah mengalami banyak perubahan. Secara tidak langsung, mereka berdampak penting bagi kehidupan beragama umat muslim di tanah air. Setiap tahun di antara mereka yang tinggal beberapa bulan di tanah suci untuk berhaji dan mencari ilmu pengetahuan dan wawasan tentang Islam dari para ulama Arab. Kemudian setelah kembali, mereka terus-menerus meniru cara-cara yang dilakukan di Mekkah.

Selain adanya upaya mempertahankan kualitas keagamaannya, ada juga di antara para alumni jamaah haji ini kembali ke praktikpraktik sebelum mereka tinggalkan berhaji. Menurut Khusna, ada beberapa pelanggaran yang paling banyak dilakukan oleh para alumni haji, di antaranya pelanggaran akidah dan pelanggaran tauhid. Sebagian dari para jamaah yang sudah berhaji, masih terkontaminasi perbuatan kemusyrikan, misalnya masih mendatangi dukun ketika ada barang yang hilang, atau bernadzar di tempat yang dikeramatkan (Khusna, 2018:143).

\section{Meningkatnya Kepedulian dan Kelas Sosial}

Haji mampu mengubah perspektif keagamaan. Haji juga menuntutnya untuk mampu mengubah konsep diri menjadi 
lebih baik, yang diindikasikan dengan perubahan perilaku yang menggambarkan manifestasi keimanan seperti keramahan, kepedulian, dan kedermawanan.

Konsep diri dalam aspek sosial pasca ibadah haji terjadi transformasi dalam konteks pergaulan di masyarakat, mereka mendapatkan pengakuan dari masyarakat sebagai penyandang gelar haji sebagai bentuk apresiasi, dan penghargaan atas keberhasilan menyelesaikan perjuangan melaksanakan ibadah yang menjadi puncak rukun Islam.

Apresiasi yang muncul dari masyarakat tidak terlepas dari persoalan sosiokultural masyarakat Indonesia yang cenderung feodal dan berpikir simbolik terhadap persoalan-persoalan yang berhubungan antara agama dan fungsi seseorang dalam masyarakat. Tidak dapat dipungkiri bahwa ibadah haji menjadi ibadah yang ekslusif dan menggambarkan prestise di tengah kesenjangan ekonomi yang terjadi di masyarakat Indonesia. Tidak sekedar persoalan kesenjangan ekonomi, ibadah haji menjadi ibadah yang ekslusif di kalangan orang yang memiliki kemampuan ekonomi sekalipun.

Transformasi citra diri dalam aspek sosial terbentuk pasca ibadah haji yang diindikasikan dengan perubahan dalam diri yang berkaitan dengan peran seseorang dalam masyarakat. Perubahan tersebut terkait dengan tuntutan dari diri sendiri untuk memerankan citra diri yang baru, tuntutan dari orang lain dan lingkungan masyarakat Indonesia yang memiliki perspektif yang berdasar pada ekspektasi terhadap penyandang gelar haji sebagai kelompok sosial baru, yang diharapkan mampu membawa misi perubahan bagi diri dan masyarakat.

Haji tidak sekedar berorientasi pada perubahan diri, tetapi pada dimensi sosial. Menurut Abdurrahman (2009:257) aktivitas ziarah sosial, baik haji maupun umrah, adalah arena-arena penting produksi sosial dan bahwa aktivitas-aktivitas seperti ini adalah contoh-contoh perebutan wilayah kekuasaan simbolik. Ziarah haji telah menghasilkan suatu kemampuan untuk menciptakan arti-arti baru di hadapan perubahan sosial yang cepat. 
Keterkaitan antara ibadah haji dengan realitas sosial yang terjadi di Indonesia, seperti dinyatakan Abdurrahman (2009: xiii) bahwa di Indonesia, terutama di kota-kota besar muncul kelas sosial baru yang modern dan kapitalistik, yaitu kelas menengah, yang dalam era globalisasi ini berusaha tetap menunjukkan jati diri sebagai orang yang saleh. Batas-batas kelas sosial, terutama dengan kelas menengah dan kelas bawah, tidak mungkin untuk diseberangi oleh kelas menengah ini untuk menjadikan mereka sama dengan kelas menengah atau kelas bawah. Mereka yang tergolong sebagai kelas menengah ini adalah mereka yang berusaha memantapkan posisi yang telah mereka peroleh, antara lain dengan cara melakukan perjalanan haji untuk dapat menunjukkan jati diri mereka sebagai golongan kelas menengah yang saleh.

Seorang muslim yang sudah berhaji akan memiliki citra diri baru, yaitu sebagai kelompok sosial "kaum yang bertakwa"; ia tidak boleh melalaikan berbagai bentuk ibadah ritual. Shalat lima waktu yang dilaksanakan secara berjemaah di masjid (khususnya bagi muslim laki-laki), dilaksanakan hanya demi memenuhi "fungsi sosial", bukan semata-mata karena Allah.

Padahal masyarakat Indonesia masih berharap kepada para jamaah haji dalam membimbingnya di dalam beribadah dan bermasyarakat. Karena ada anggapan di Indonesia kalau orang yang telah pulang dari menunaikan ibadah haji, akan menjadi kiblat bagi orang-orang di sekitarnya. Secara tidak langsung, masyarakat yakin kalau orang yang sudah pergi haji bisa dijadikan imam atau panutan, dimintai doa juga dimintai pendapat atau nasihatnya (Rokhmad dan Choliq, 2015: 238).

\section{Mendapat Label Orang Suci dan Membentuk Kesalehan Sosial}

Perubahan konsep diri seorang muslim setelah berhaji semestinya menyangkut aspek-aspek prinsip yang menggambarkan kesalehan individu, yang pada gilirannya memiliki pengaruh terhadap kesalehan sosial. Namun demikian, perubahan diri pasca haji seringkali terjadi hanya di sekitar wilayah simbolik, yang menggambarkan citra diri baru seorang yang telah melaksanakan ibadah haji. Citra diri seorang yang telah berhaji secara simbolik dibentuk melalui penggunaan simbol-simbol verbal dan nonverbal. 
Orang yang telah selesai melaksanakan ibadah haji dianggap sebagai "orang suci", yang berimpliksi pada adanya ekspektasi terhadap dirinya untuk mengimplementasikan nilai-nilai keislaman dalam kehidupan sosialnya. Ekspektasi tersebut muncul dari orangorang yang dianggap penting (significant other) baik di lingkungan keluarga, masyarakat sekitar, lingkungan pekerjaan maupun masyarakat umum.

Bentuk apresiasi dan penghormatan terhadap orang yang selesai melaksanakan ibadah haji dengan panggilan "haji" untuk laki-laki, atau "hajah" untuk perempuan dalam pergaulan seharihari. Selain itu, adanya penyantuman gelar "H" atau "Hj" dalam rangkaian gelar kehormatan di masyarakat. Pelaberan dan pemberian gelar ini secara secara alamiah, sehingga bagi seorang "haji" baru memunculkan perasaan kurang nyaman pada saat pertama kali mendapat panggilan yang menggambarkan status sosial yang lebih tinggi dibanding masyarakat pada umumnya. Namun seiring waktu, labelling pada dirinya dan berubah menjadi label yang melekat dalam diri seseorang, bahkan terasa "ada yang kurang" ketika gelar atau panggilan haji tidak disertakan dalam komunikasi sehari-hari.

Selain pesan-pesan verbal, pasca pelaksanaan ibadah haji terjadi pengelolaan kesan untuk membentuk citra diri baru melalui pesan-pesan nonverbal melalui pesan artifaktual, yaitu penggunaan pakaian dan aksesoris yang menggambarkan seorang yang memiliki citra diri baru sebagai seorang yang lebih alim, lebih saleh dan lebih taat.

Pakaian dan aksesoris tersebut berupa peci haji, sorban dan aksesoris lainnya. Sebagian orang bahkan masih menggunakan "gelang haji", sebagai identitas jamaah haji Indonesia ketika berada di Tanah Suci yang di dalamnya terdapat nama jamaah, nomor paspor dan tulisan Jamaah Haji Indonesia lengkap dengan lambang negara Indonesia. Ada juga sebagian jamaah haji masih memakai seragam jaket atau baju batik khas haji dalam kehidupan sehari-hari, untuk menampilkan citra diri sebagai seorang yang sudah berhaji.

Seseorang semestinya tidak terjebak dalam gelar penghormatan yang diberikan oleh masyarakat, khususnya panggilan haji atau hajjah, sebab yang terpenting adalah bagaimana substansi dari 
gelar yang melekat dalam diri seseorang, yaitu mengamalkan nilainilai dan ajaran agama secara benar dan konsisten, sebagai wujud implementasi haji mabrur.

Pandangan ini sejalan dengan Saputra, bahwa orang yang sudah berhaji memaknai ibadah haji adalah harus meningkatnya kepedulian kepada lingkungan sosialnya. Bukan sekedar mendapatkan sebutan haji atau hajjah, justru ibadah haji lebih banyak makna sosialnya daripada makna ritual (transendental) (2016:89).

Masyarakat Indonesia sebenarnya menyadari bahwa panggilan haji dan penyantuman gelar haji pada nama seseorang merupakan peristiwa simbolik yang melekat dengan tradisi bangsa Indonesia. Sebenarnya mereka menyadari realitas tersebut, namun pada kenyataannya kebanyakan dari mereka terjebak dalam tradisi yang sudah menjadi bagian penting dari interaksi dan komunikasi masyarakat Indonesia yang cenderung feodal.

Pada awalnya seorang yang sudah berhaji merasa risi untuk dipanggil haji, tapi lama-kelamaan terbiasa dengan panggilan tersebut, walaupun hati kecilnya mengingkarinya karena dapat menjadi beban bagi dirinya berkenaan dengan konsekuensi seorang yang sudah berhaji di persepsi masyarakat Indonesia sebagai orang yang harus menampilkan sikap dan perilaku yang baik.

Haji lebih penting substansinya dibanding simbol yang terkait dengan ibadah. Fakta yang terjadi di masyarakat Indonesia tidak dapat dihindari untuk yang terkait dengan pasca pelaksanaaan ibadah haji. Pada umumnya terdiri dari kalangan berpendidikan dan kelompok sosial menengah ke atas, yang memiliki karakteristik sebagai jemaah haji yang lebih mengedepankan aspek-aspek yang mencerminkan sikap dan perilaku penyandang haji mabrur.

Sebenarnya dalam diri seorang yang telah melaksanakan ibadah haji, menyadari substansi ibadah haji lebih pada perubahan diri, bukan pada simbol-simbol verbal atau nonverbal. Tetapi seringkali dia sulit menghindari tradisi yang sudah berkembang di masyarakat Indonesia, yang pada umumnya menganggap haji sebagai peristiwa penting yang menggambarkan prestise, dan status sosial seseorang di tengah masyarakat. 
Pada dasarnya, seorang yang sudah berhaji tidak mementingkan aspek-aspek simbolik, dan gelar atau sebutan haji pasca pelaksanaan haji. Karena itu merupakan tradisi masyarakat Indonesia yang menganut budaya konteks tinggi, dan banyak melakukan komunikasi simbolik sebagai bentuk penghormatan seseorang kepada orang lain yang lebih tua, atau memiliki status sosial yang lebih tinggi. Hal yang sama juga dikatakan Kisworo, bahwa bukan titel "Pak Haji" atau "Bu Hajjah", bukan "peci putih" atau "mukena putih" sebagai simbol haji mabrur, melainkan "hati yang putih" sebagai pengejawantahan kepasrahan total keimanan kepada Zat Yang Maha Memiliki (Kisworo, 2017:75).

Tidak adanya status sosial dalam haji bisa dilihat pada pakaian ihran ketika berhaji. Pakaian ihram berfungsi sebagai lambang kesatuan dan persamaan, sehingga hilanglah perbedaan status sosial. Semua jamaah yang menggunakan pakaian ihram menjadi satu yaitu sebagai hamba-hamba Allah SWT yang merindukan keridlaan-Nya (Saputra, 2016: 98). Pandangan Istianah memperkuat bahwa pakaian ihram telah mengajarkan kita untuk untuk menanggalkan semua perbedaan, serta menghapus segala keangkuhan yang ditimbulkan dari status sosial (2016: 30).

Kemudian sepulang dari tanah suci, jamaah haji melepaskan pakaian ihramnya, tetapi spiritual baju ihram akan tetap terpakai. Baju ihram lahir hanya menutupi jasad, sedangkan baju ihram batin akan menutupi hati dan jiwa (Rokhmad dan Choliq, 2015: 237). Artinya sekembali dari tanah suci, meskipun kain ihram sudah tidak lagi dipakai, tetapi hati dan jiwa tetap terjaga untuk tidak mengagungkan status sosial.

Justru sepulang dari haji, sebaiknya melaksanakan tugas sebagai perubahan sosial. Karena prosesi haji menempati peran yang sangat signifikan sebagai pencipta agent of change bagi sebuah masyarakat dan bangsa dalam menuju kondisi yang ideal. Itulah substansi haji yang diproyeksikan agar umat menjadi manusia unggul (insan kamil), yaitu manusia yang memiliki kemampuan untuk melakukan perubahan sosial di lingkungannya, yang dimulai dengan perubahan mentalnya (revolusi mental) (Rokhmad dan Choliq, 2015: 6). 


\section{Kesimpulan}

Jamaah haji sebelum melaksanakan ibadah haji sudah melakukan transformasi konsep diri, yaitu sebagai calon jamaah haji yang kurang memahami tentang haji, dan mengamalkan ajaran-ajaran agama seperti ibadah mahdoh dan ghair mahdoh. Meskipun belum menunaikan haji, calon jamaah haji sudah merasakan sensasinya sebagai calon haji yang akan meningkat status sosialnya di masyarakat. Kemudian transformasi yang kedua terjadi ketika jamaah haji ini selesai dan kembali ke kampung halaman sebagai haji. Banyak di antara mereka yang mengalami 'gegar budaya' dengan status haji. Namun di antara jamaah haji memiliki tugas dan beban yang berat juga untuk mempertahankan kemabrurannya setelah berlatih di tanah suci untuk mendapatkan haji mabrur.

Penelitian mengenai ibadah haji telah banyak dilakukan dalam berbagai perspektif dan pendekatan, namun penelitian ibadah haji dari dimensi komunikasi masih jarang dilakukan. Penelitian ini belum mengungkap secara komprehensif mengenai dimensi-dimensi komunikasi dalam ibadah haji. Oleh karena itu, masih sangat terbuka bagi para peneliti lain yang memiliki minat sama seputar pelaksanaan ibadah haji, khususnya komunikasi antarbudaya. 


\section{Daftar Pustaka}

Abdurrahman, Moeslim. 2009. Sersujud di Baitullah: Ibadah Haji Mencari Kesalehan Hidup. Jakarta: PT Kompas Media Nusantara.

Bungin, Burhan. 2003. Analisis Data Penelitian Kualitatif. Jakarta: PT Raja Grafindo Persada.

Dewey, Richard dan Humber, W.J. 1967. An Introduction to Social Psychology. London: Collier-Mcmilan.

Direktorat Jenderal Penyelenggaraan Haji dan Umrah Kementerian Agama RI. 2016: Fiqh Haji Komprehensif. Cet. Ke-2, Jakarta: Kementerian Agama RI: Direktorat Jenderal Penyelenggaraan Haji dan Umrah.

Fithria, 2011. Hubungan Komunikasi Keluarga dengan Konsep Diri Remaja. Idea Nursing Journal. Vol. II No. 1.

Hamidah dan Anganthi, Nisa Rachmah Nur. 2017. Strategi Coping Pada Jamaah Haji Tunanetra. Jurnal Indigenous Vol. 2 No. 1.

Irawan, Sapto. 2017. Pengaruh Konsep Diri terhadap Komunikasi Interpersonal Mahasiswa. Jurnal Scholaria. Vol. 7 No 1.

Istianah. 2016. Prosesi Haji dan Maknanyaa. Jurnal Akhlak dan Tasawuf Volume 2 Nomor 1.

Japeri. 2017. Pengaruh Prediket Haji Mabrur Terhadap Motivasi Manasik Calon Jamaah Haji. Maqdis: Jurnal Kajian Ekonomi Islam. Volume 2, Nomor 1.

Kisworo, Budi. 2017. Ibadah Haji Ditinjau Dari Berbagai Aspek. Al Istinbath: Jurnal Hukum Islam vol. 2, no. 1.

Kholilurrohman, 2017. Hajinya Lansia Ditinjau dari Perspektif Bimbingan dan Konseling Islam. Al-Balagh Jurnal Komunikasi dan Dakwah. Vol. 2, No. 2

Khusna, Azalia Mutammimatul. 2018. Hakekat Ritual Ibadah Haji dan Maknanya Berdasarkan Pemikiran William R. Roff. AnNas: Jurnal Humaniora. Volume 2, Nomor 1. 
Malcom dan Haley, Alex. 1965. The Autobiography of Malcom X, New York: Groove Press.

Mead, George Herbert. 1934. Mind, Self, and Society: From the Stanpoint of A Social Behaviorist. Chicago: University of Chicago Press.

Rakhmat, Jalaluddin. 2015. Psikologi Komunikasi. Cet.ke-30. Bandung: Remaja Rosdakarya.

Rokhmad, Ali. 2016. Manajemen Haji: Membangun Tata Kelola Haji Indonesia. Jakarta: Media Dakwah.

Rokhmad, Ali. dan Choliq, Abdul. 2015. Haji Transformasi Profetik Menuju Revolusi Mental. Jakarta: Media Dakwah.

Saerozi, Muh. 2014. Teknik Pembelajaran Kolaboratif untuk Memandirikan Calon Jamaah Haji Pada Kelompok Bimbingan Haji Masjid Istiqamah Unggaran. INFERENSI, Jurnal Penelitian Sosial Keagamaan. Vol. 8, No. 1.

Saliyo, 2018. Pengaruh Religiusitas Jamaah Masjid Az-Zuhud Petanahan Kebumen Terhadap Perilaku Toleransi Beragama dengan Kepribadian yang Dimilikinya. INFERENSI, Jurnal Penelitian Sosial Keagamaan. Vol. 12, No.1.

Saputra, Agus Romdlon. 2016. Motif dan Makna Sosial Ibadah Haji Menurut Jama'ah Masjid Darussalam Wisma Tropodo Waru Sidoarjo. Kodifikasia, Volume 10 No. 1.

Strauss, Anselm L. 1959. Mirrors and Masks: The Search for Identity. Glencoe: The Free Press

Wulandari, Tine Agustin. 2014. Hubungan Antara Konsep Diri Dengan Keefektivan Komunikasi Antarpribadi: Studi pada Anggota AIESEC Local Committee (LC) Bandung. Jurnal Kajian Komunikasi, Volume 2, No. 2.”. December: 315-331. DOI:https://doi.org/10.30596/ intiqad.v10i2.2491.

Ramayulis. 1994. Ilmu Pendidikan Islam. Jakarta: Kalam Mulia.

Ricci, Nino. 2002. "What is Multiculturalism?" dalam Journal of Canadian Heritage Multiculturalism, vol. March 21, http: // 
www.pch.gc.ca/multi/ what-multi-e.shtml.

Rinanto. 2016. Skripsi; Sejarah dan Perkembangan Muhammadiyah Cabang Kecamatan Weleri Kabupaten Kendal Tahun 19302015: 7-12.

Sachedina, Abdulaziz. 1990. The Islamic Roots of Democratic Pluralism. New York: Oxford University Press.

Sarbini, Ahmad. 2010. "Internalisasi Nilai Keislaman melalui Majlis Taklim”. Jurnal Ilmu Dakwah Vol. 5 No. 16 Juli-Desember: 53-68.

Setiawati, Nur. 2012. "Majelis Taklim dan Tantangan Pengembangan Dakwah”, Jurnal Dakwah Tabligh, Vol. 13, No. 1 (Juni 2012): 81-95.

Savitri, Sitria 2016. https://mediaindonesia.com/read/detail/52776majelis-taklim-redam-radikalisme.$h t m l$

Sleeter. 1994. dalam Burnett, G., Varieties of Multicultural Education: an Introduction. Eric learinghouse on Urban Education, Digest.

Sulaiman, Kamal-deen Olawale. 2016. "Religious Violence in Contemporary Nigeria: Implications and Options for Peace and Stability Order". Pretoria: Journal for the Study of Religion: vol.29 no.1 ISSN 2413-3027. ISSN 1011 7601.http:// www.scielo.org.za/ scielo.php?script=sci _arttext\&pid=S1011-76012016000100004

Suparlan, Supardi. 2002. "Menuju Masyarakat Indonesia yang Multikultural", Makalah Simposium Internasional ke-3, Jurnal Antropologi Indonsia, Denpasar Bali, 16-21 Juli: 98-103. DOI https://doi/org/10.7454/ai.v0i69.3448

Suparta, Mundzier, \& Haedari, Amin. 2003. Manajemen Pondok Pesantren. Jakarta: Depag.

Suparta, Mundzier. 2008. Islamic Multicultural Education: Sebuah Refleksi atas pendidikan Agama Islam di Indonesia. Jakarta: Al Ghazali Center.

Syafar, Muhammad. 2018. "Pemberdayaan Komunitas Majelis Taklim di Kelurahan Banten Kecamatan Kasemen Kota Serang". 
Lembaran Masyarakat: Jurnal Pengembangan Masyarakat Islam Vol. 1 No 1.: Januari-Juni: 41-68.

Taufani \& Wekke, Ismail Suardi. 2017. "Dinamika Anti Syiah di Kota Manado". Makalah dipresentasikan pada: International Symposium on Frontiers of Southeast Asia Studies (ISoFSEAS) di Kuala Terengganu, Malaysia. 9 - 11 October. DOI: 10.31227/ osf.io/8asbz

Tilaar, H.A.R. 2009. Multikultualisme, Tantangan-tantangan Global Masa Depan dalam Transformasi Pendidikan Nasional. Jakarta: Grasindo.

Tim dan Penulis Departemen Agama. (2008). Pedoman Pengelolaan Majlis Taklim. Jakarta: Dipendis Ditjen PAI Departemen Agama RI.

Umar, Nasaruddin. 2018. Keberadaan Majlis Ta'lim, https://rmol.id/ $\mathrm{read} / 2018 / 03 / 21 / 331698 /$

Winn, Phillip. 2012. "Women's Majelis Taklim and Gendered Religious Practice in Northern Ambon". Intersections Gender and Sexuality in Asia and the Pacific". Issue 30, November. URL: http://intersections.anu.edu.au/issue30/winn.htm

Yaqin, Ainul M. 2005. Pendidikan Multikultural: Cross-Cultural Understanding untuk Demokrasi dan keadilan. Yogyakarta: Pilar Media.

Zaimeche, Saleh. 2002. Education in Islam - The role of the Mosque. United Kingdom : Foundation for Science Technologi and Civilisation.

Zainiyati, Husniyatus Salamah. 2016. "Curriculum, Islamic Understanding and Radical Islamic Movements in Indonesia". Journal Of Indonesian Islam, Volume 10, Number 02, December: 285-308. DOI: 10.15642/JIIS.2016.10.2.

Zamroni. 2011. Pendidikan Demokrasi pada Masyarakat Multikultural. Yogyakarta: Gavin Kalam Utama.

Zulfa, M. 2015. "Transformasi dan Pemberdayaan Umat Berbasis 
Imron Rosyidi, Encep Dulwahab

Masjid: Studi Pada Masjid Nurussa'adah Salatiga”. Inferensi Jurnal Penelitian Sosial Keagamaan Vol. 9, No. 1: 257-278. 